\title{
Fracturing the "Exception": The Legal Sanctioning of Violent Interrogation Methods in Israel since 1987
}

Irit Ballas

This article examines the legal constructs governing the use of violent interrogation methods in Israel since 1987. It explores the shift from a sweeping suspension of the prohibition on torture to a fractured legal regime in which the different elements of interrogation - the perpetrator, the victim, the time of the interrogation, and the space in which it takes place-are effectively excluded from the prohibition on torture by means of separate legal constructs. I show how each of these constructs creates a narrow, seemingly proportional exception to ordinary law. Together, the four types of exception facilitate the sanctioning of state violence. I use this case to analyze the available configurations of the state of exception, distinguishing them from each other by what they exclude from ordinary law. By showing how the proliferation of legal constructs produces an entire ecosystem of different exceptions, I point to the inherent link between the suspension of the law and its proliferation: both create legal categories that rationalize and legitimize state violence.

\section{INTRODUCTION}

The "state of exception" is a key concept for understanding the role of law in sanctioning state violence. When a special need arises, states suspend the restraints on the executive found in ordinary law (Hussain 2007; Kahn 2008; Luban 2014; Reynolds 2017). As part of the "war on terror," for instance, the United States imposed a state of emergency, declared martial law, and marked certain detention facilities as extraterritorial in order to sanction practices that were not allowed in the state's territory (Dershowitz 2003; Greenberg 2005; Scheppele 2005a; Bellamy 2006; Gross 2007; Rejali 2007; Hajjar 2013; Luban 2014; Viterbo 2014). As recent scholarship has pointed out, such suspensions of the law are not necessarily tantamount to lawlessness. In fact, states may reduce the legal restraints imposed on them by introducing an alternative, more permissive legal arrangement, codified in special regulations or decrees (Gathii 2003; Scheppele 2005b; Rejali 2007; Luban 2014; Reynolds 2017).

Recently, scholars have questioned whether it is the suspension of law that allows for the sanctioning of state violence (Johns 2005; Hussain 2007; Lokaneeta 2011; Nieminen 2019). Discussing the interrogation practices at Guantanamo Bay, Nasser

Irit Ballas, Department of Sociology and Anthropology, Tel Aviv University, Israel; Board member, Public Committee against Torture in Israel. Email: irit.ballas@gmail.com

The author thanks Smadar Ben-Natan, Gideon Freudenthal, Lisa Hajjar, Amos Israel, Carmi Lecker, Jinee Lokaneeta, Guy Lurie, Itamar Mann, Yehouda Shenhav, and Rachel Stroumsa for their helpful comments on earlier drafts. All interpretations and errors are the author's own. 
Hussain (2007, 735) has suggested that "the exception as it has historically and theoretically been understood, as a suspension of regular law, even a space of non-law, no longer exists." Instead, he argues, the treatment of security suspects is now characterized by "hyper-legalization"-the proliferation of legal categories and venues. This view echoes the longstanding criticism of liberal thought in which the law is viewed as an articulation of state violence and not of its restriction (Cover 1985; Lokaneeta 2011; Viterbo 2014). Its proliferation, therefore, inevitably increases such violence.

In this article, I describe how the legal regulation of violent interrogation methods used by the Israeli Security Agency (ISA, widely known as Shin Bet or Shabak) has undergone a similar process of proliferation. In 1987, the Landau Commission (1987), a governmental commission of inquiry charged with examining the legality of the use of physical interrogation methods, granted ISA interrogators a sweeping exemption from the prohibition on torture. Without specifying times, victims, or circumstances, it asserted that in ISA interrogations the use of violent means of interrogation may be permitted. ${ }^{1}$ In 1999, the High Court of Justice (HCJ) rejected this sweeping exemption in a landmark ruling (Public Committee against Torture $v$. State of Israel 1999). However, the state's legal authorities subsequently constructed a wide range of legal categories and stipulations in order to govern the use of violent methods in ISA interrogations.

Contrary to Hussain's argument that the proliferation of the law has replaced its suspension, in this case at least, the proliferation of the law constitutes a fracturing of this suspension into four distinct exceptions. While the HCJ ruling rejected the wholesale suspension of the prohibition on torture approved by the Landau Commission's (1987) report, it introduced a legal construct by which the interrogator-that is, the potential perpetrator of violent interrogation methods - may be excluded from criminal liability. Immediately after the ruling, the Attorney General also issued guidelines that excluded certain periods of time during the interrogation from the ordinary rules of conduct. In addition to these two constructs, the laws of criminal procedure deny most ISA interrogees - that is, potential victims - legal protections given to other detainees by labeling them "security suspects." Finally, ISA interrogations most commonly take place in special wings of ordinary detention facilities but are not subject to the mechanisms that oversee those facilities. This creates a physical space that is excluded from the restrictions found in ordinary law. I argue that the proliferation of legal categories that now govern the use of violent methods of interrogations is nothing but the fracturing of one sweeping exception into a set of designated exceptions, each targeting a different component of ISA interrogations.

Scholars studying the state of exception have recognized each of these four configurations. Historians of colonial legal history have shown how, in colonial contexts, excluding perpetrators from criminal liability has been the accepted outcome of the declaration of martial law (Hussain 2003; Shenhav 2012). In a contemporary context, Austin Sarat and Conor Clarke (2008) propose that a prosecutor's decision to press

1. There is much debate on the definition of torture versus the less severe category of "cruel, inhuman and degrading treatment" (Nowak 2006; Viterbo 2014). Many of the commonplace interrogation methods in Israel might fall under the definition of torture in international law. However, my concern here is with the methods that are illegal under ordinary Israeli law and necessitate the creation of an exception. These include methods that may or may not fall under the definition of torture in international law. 
charges represents, in fact, a moment of "exceptionalism" because it reflects the ability to exempt individuals from the purview of the legal order. Temporal suspensions of the law are the ones most commonly associated with emergencies because states justify the suspension of ordinary law by claiming that a certain time is especially dangerous and therefore requires a more lenient set of rules for state actors (Gross 2000; Loevy 2016). This holds true even if they extend the emergency indefinitely (Neal 2012). Drawing heavily on Giorgio Agamben, scholars have shown how states construct legal categories to deny certain people the protections of the law (Ek 2006; Giaccaria and Minca 2011). Finally, they have also highlighted the many ways in which legal categories may create exceptional spaces (Ek 2006; Kelly 2006; Braverman et al. 2014).

While the literature has addressed each of the configurations of the exception, it has not explicitly acknowledged that different exceptions differ from each other by what they exclude from ordinary law. Therefore, to date, it has not examined the differences between the types of exception, nor has it elaborated on the opportunities each type presents for the state. Moreover, commentators have failed to examine how states can combine different exceptions, located in different areas of the law and administered by different authorities, in order to suspend the protections granted by ordinary law in an inconspicuous manner. The analysis that follows in this article has two tiers, each relying on a different set of empirical sources. In the first tier, I focus on Israel's official position on methods of interrogation. I examine a wide range of official documents that present and justify the official position regarding the legality of ISA interrogation methods. The documents include reports by commissions of inquiry, government directives and guidelines, and $\mathrm{HCJ}$ rulings from the years between 1987 and 2018. ${ }^{2}$ Most documents have been translated into English ${ }^{3}$ and have received much scholarly attention (Imseis 2001; Reichman 2001; Scheppele 2005a; Goldstone 2006; Mann and Shatz 2010; Hajjar 2013; Luban 2014). My contribution lies in a novel interpretation of these documents: I suggest that they did not merely change the scope of the exception that allowed the ISA to use violent interrogation methods but that they also generated a whole ecosystem of designated exceptions.

In the second tier of the analysis I examine exceptions that suspend safeguards, including both procedural rights-for example, the right to counsel and the judicial oversight of arrest - and oversight mechanisms for monitoring the welfare of detainees. I analyze the procedures and guidelines pertaining to the arrest and detention of ISA interrogees. Whereas these exceptions do not explicitly permit violent interrogation methods, it is widely understood that they play a crucial role in facilitating the use of such methods (Kelly 2009; Mann and Shatz 2010; Lokaneeta 2011; Carver and Handley 2016). Thus, the two tiers of the analysis are complementary, and both are essential for understanding the scope of the fractured legal regime that now governs the violent methods of interrogation employed by the ISA.

In the first part of this article, I describe the legal and political context in which ISA interrogations take place. This is followed by an analysis of the sweeping suspension

2. I chose this period because violent Israeli Security Agency (ISA) interrogation methods were officially sanctioned by the Landau Commission in 1987, and the last relevant ruling on the topic was handed down in 2018 (Tbeish v. Attorney General 2018). The/An English Translation is available at http://versa. cardozo.yu.edu/sites/default/files/upload/opinions/Tbeish\%20v.\%20Attorney\%20General.pdf.

3. I provide a reference to the English translation of all translated documents. Some documents used for the analysis are available only in Hebrew. 
of the prohibition on torture established by the report of the Landau Commission (1987), the first document that officially sanctions violent interrogation methods. I show that it resembles other emergency legislation in that it formulates an alternative, more lenient set of rules that applies to all ISA interrogations at all times (Loevy 2016; Reynolds 2017). Next, I present the four designated exceptions that now govern ISA interrogations: an exception excluding the perpetrator from the scope of criminal liability; an exception excluding the victim from the protection of safeguards; an exception excluding certain phases of the interrogation from the prohibition on violent interrogation methods; and an exception excluding the space in which the interrogation takes place from oversight. For each exception, I present the legal rule, category, or policy that established it, the scope and the boundaries of the exception it created, and its advantages for the executive. I examine the different ways in which legal officials justified these exceptions and the underlying perceptions of the rule of law they reflect. Then I analyze a recent HCJ ruling in which the judges condoned the use of violent interrogation methods, basing their ruling on all four exceptions. In the concluding part, I explore how the two paradigms-one in which state violence is linked to the state of exception and one in which it is linked to the proliferation of the law-can coalesce, as both introduce new legal categories in order to make state violence appear more rational and justified.

\section{ISA INTERROGATION METHODS: BACKGROUND AND CONTEXT}

Emergency measures have been part and parcel of Israeli law since the state's establishment (Kelly 2006; Mehozay 2016; Robinson 2013; Reynolds 2017; Berda 2017). Like other settler societies, Israel has used such measures to expropriate land and property and to limit access by the indigenous Palestinian population to resources and rights (Lloyd 2012; Robinson 2013; Sa'di 2016; Reynolds 2017). When Israel occupied what is now called the Occupied Palestinian Territories (OPT) in 1967, it used many of these emergency measures to confiscate land, guarantee economic dependence, and generally facilitate the settlement project (Kelly 2006; Gordon 2009; Berda 2017; Reynolds 2017). In this context, it still uses such measures to foil Palestinian opposition to the occupation (Hofnung 2001; Reynolds 2017). Two legislative regimes provide the legal basis for sanctioning the arrest, interrogation, and indictment of Palestinians: military decrees that are part of military rule in the OPT and security legislation in Israeli law. Both are regimes of exception in that they suspend the rights of detainees because, supposedly, they pose some special danger.

Over the years, the ISA has established an extensive system of information gathering in the OPT, relying heavily on interrogations. A typical interrogation begins with an arrest and takes place in a special wing of a detention center in Israel or the OPT. Ostensibly, these interrogations are separate from the criminal proceedings launched by the police against the same subject (Hajjar 2005). ${ }^{4}$ For many years, ISA interrogation

4. The legal arrangements governing interrogations reflect their different objectives. The ISA is intent on gathering intelligence, the police on investigating a crime and initiating a criminal procedure. Even when an ISA interrogee provides incriminating information, de jure the police cannot use it in a criminal legal procedure. However, human rights organizations have noted that, de facto, the police and the ISA 
methods were rarely questioned publicly. Evidence of violent interrogations was sporadic, and state officials either ignored or denied claims of torture. ${ }^{5}$ This situation changed after two scandals that caused a public outcry. The first was the "Bus 300 affair." In 1984, four Palestinians hijacked a bus full of Israeli civilians. One of the hijackers was beaten to death in police custody, and the cover-up attempt caused a public outcry (Gutman 1995; Pascovich 2015). The second incident involved Izzat Nafsu, an Israeli Circassian army officer sentenced in 1982 to an eighteen-year prison term for treason and espionage. At his "trial within a trial" (voir dire procedure), Nafsu maintained that his confession had been extracted under duress in the course of an ISA interrogation (Lieutenant Izzat Nafsu v. Chief Military Advocate 1987; Pascovich 2015). The ISA officers denied this under oath, both in the original court-martial and in the military court of appeals. However, in May 1987, the HCJ accepted Nafsu's appeal and ordered his release (Izzat Nafsu v. Attorney General 1988).

The resulting public outcry prompted the government to appoint a commission of inquiry, led by Justice Moshe Landau, to examine the legality of the methods used in ISA interrogations relating to "hostile terrorist activity" (Landau Commission 1987, 1.1). The appointment of the Landau Commission marked the beginning of a new era. Rather than denying the existence of violent interrogation methods, the government now instructed legal officials to regulate their usage (Imseis 2001; Hajjar 2013).

\section{A SWEEPING SUSPENSION}

The Landau Commission attempted to subject ISA interrogations to the authority of the law (Imseis 2001; Ginbar 2009; Mann and Shatz 2010). In its report, the commission repeatedly states that no act of the state is above the law and no danger can justify actions of which the state's legal officials do not approve: "The law itself must ensure a proper framework for the activity of the GSS [General Security Service] ${ }^{6}$ in its investigations of hostile terrorist activity, with all their attendant problems and dilemmas" (Landau Commission 1987, 4.5). This zealous stance toward the rule of law may explain why the commission dedicates a major part of its report to what it evidently regards as its most troubling finding: that ISA interrogators had been systematically lying in court about the use of violence in interrogations. The commission strongly

coordinate their activities. The ISA may arrange, for instance, for the police to launch a criminal procedure against an individual in order to pressure him into providing information to his ISA interrogators. The police, in turn, may use an ISA interrogation, with its harsher methods, to extract a confession that they can use in a criminal trial. See Public Committee against Torture in Israel 2009.

5. The relatively few publications from the early post-1967 period include: an International Committee of the Red Cross (1968) report on Nablus prison; As'ad Abdul Rahman's (1969) account of his ten months in Israeli prisons in Sarafand, Jerusalem, Ramla and Ramallah; a United Nations Economic and Social Council (1970) report containing evidence of the mistreatment of prisoners; Amnesty International's (1970) Report on the Treatment of Certain Prisoners under Interrogation in Israel; a report by the Israeli League for Human and Civil Rights on the detention conditions in the Gaza Strip (1971); a Sunday Times (1977) article on torture in Israel; a publication on this topic by the American National Lawyers Guild (1978); and the International Commission of Jurists's (1984) report on Al Farah prison. All of these publications reveal extremely violent methods of torture, such as electric shocks, tiny confinement cells, and sexual molestation.

6. General Security Service was the official name of what is today called the ISA. 
condemns this "dismal and regrettable" practice. The ISA, it states, "did not understand that it was entrusted with a vital task, which perhaps justifies the means, but not all means, and certainly not the means of giving false testimony" (2.53).

While condemning perjury, the Landau Commission regards the actual use of violent interrogation methods as reasonable and, more importantly, necessary. It emphasizes that it had heard the testimony of many experts and that these experts were unanimous in their view that a certain degree of violence in interrogations is the only way to extract information that might save human lives (Landau Commission 1987, $2.37,4.6)$. These two points - that all state actions should be subject to the rule of law and that violent methods of interrogation are necessary for the work of the ISA - led the Landau Commission to what it considered its inevitable conclusion: that a special legal regime permitting extraordinary measures was required. In this way, everything would be done according to the law, albeit a special law that reflected the need to cope with a special kind of danger (Scheppele 2005b; Reynolds 2017). To that end, the Landau Commission enlisted the "necessity defense" in the criminal code and determined that ISA interrogators were permitted to use violent interrogation methods to save human lives. The commission attached a list of approved interrogation methods, which it regarded as representing the proper balance between the special needs of the ISA and the need to protect the rights of interrogees (Landau Commission 1987, 4.6). In doing so, the commission crafted a legal construct that provided for an alternative, codified prescription for the use of violence.

As the literature on emergency legislation has pointed out, the assumption underlying this type of legal regime is not that it will apply to a single, unpredictable event but, rather, that such events will occur regularly (Townshend 1982; Hussain 2003; Reynolds 2017) The state must therefore formulate a code of conduct for the use of violence (Scheppele 2005b; Hofnung and Margel 2010; Reynolds 2017). Such a construct does not lift all the restraints on the executive. Instead, it excludes certain sections of the executive's activity from the scope of ordinary legal prohibitions and subjects it to an alternative, more permissive, set of rules (Furedi 1993; Gross 2000; Scheppele 2005b; Loevy 2016; Berda 2017).

The Landau Commission emphasized that the ISA's adherence to this new legal regime was as important as its adherence to any other law, and it reiterated its ultimate objective: subjecting the sovereign to the rule of law: "Great care must be taken lest a breach in the structure of the prohibitions of the criminal law bring about a loosening of the reins, with each interrogator taking matters into his own hands through the unbridled, arbitrary use of coercion against a suspect" (Landau Commission 1987, 3.16). The commission warned that, if Israel failed to impose legal constraints on interrogations, "the state as a law-abiding polity which preserves the rights of its citizens is likely to be irreparably perverted, with it coming to resemble those regimes which grant their security organs unbridled powers" (3.16). This concern with the appearance of the rule of law is typical of legal officials crafting emergency laws (Townshend 1982; Hussain 2003; Scheppele 2005b; Reynolds 2017).

As many scholars have noted since the publication of the Landau Commission's (1987) report over thirty years ago, its interpretation of the "necessity defense" is highly unusual (Morgan 2000; Bellamy 2006; Hajjar 2013). In criminal law, the necessity defense can be used to exonerate a specific individual from criminal liability (Gaeta 
2004; Gross 2007; Ramraj 2008). It relates to a single decision to break the law, made in light of extreme and unpredictable circumstances. However, the Landau Commission's interpretation created a new legal rule that subjected all ISA interrogations, at all times, to an alternative legal regime, which created a different prescription for the use of violence from that governing ordinary interrogations. ${ }^{7}$ It is precisely the all-encompassing nature of this alternative regime that was rejected by the HCJ in 1999.

\section{SPLITTING UP THE SWEEPING SUSPENSION}

The years following the Landau Commission's (1987) report were also the years of the first intifada, the Palestinian uprising. Mass arrests and allegations of the widespread use of violent methods of interrogation followed. ${ }^{8}$ In the course of the 1990 s, several human rights organizations petitioned the HCJ, demanding that the court prohibit the use of such interrogation methods. The court finally addressed the issue in a landmark ruling handed down in September 1999. In its ruling, the court affirmed that in ordinary law violent interrogation methods are forbidden. More importantly, it determined that the ISA does not enjoy a special legal status just because it deals with a special type of danger. In other words, the legal construct created by the Landau Commission, which subjected ISA interrogations to a more lenient legal regime, was illegal. ISA interrogations should be subjected to the same legal constraints as other interrogations (Public Committee against Torture in Israel 1999, 32, 36).

The HCJ's interpretation of the rule of law, therefore, was much stricter than the Landau Commission's. One consolidated state law, as all-encompassing as possible, should apply to all interrogations at all times. However, the court did not entirely repudiate the commission's sweeping suspension of ordinary law but, rather, introduced an exception targeting just one element of ISA interrogations-the perpetrator.

\section{First Fracture: The Perpetrator}

The ruling did not entirely discard the possibility that special circumstances may justify special means. In such special circumstances, the perpetrator could be exonerated from criminal liability using the necessity defense from criminal law. However, the HCJ's interpretation of the necessity defense differed from that of the Landau Commission: "Potential criminal liability shall be examined in the context of the necessity defense. Provided the conditions of the defense are met by the circumstances of the case, the investigator may find refuge under its wings" (Public Committee against Torture in Israel 1999, 38). The ruling emphasized that this defense should be applied

7. The term "necessity" is not restricted to an exemption from criminal liability. It is often used interchangeably with what I call here "emergency," a suspension of the state's obligation to uphold rights entrenched in ordinary law (Mahmud 1993). Such is the definition of "military necessity" in international humanitarian law. The interchangeable use of the two terms points to a mutual genealogy. They have, however, evolved into two different forms of the exception, one a defense in criminal law and the other an exception to constitutional obligations. I use them here in this latter sense and point to the distinction between them.

8. See, for example, B’Tselem $(1992,1998)$. 
on a case-by-case basis and should cover acts not approved ex ante but, rather, "as the result of improvisation, given the unpredictable character of the events" (36).

Exonerating public officials from criminal liability in times of necessity is by no means a novelty. Historically, such exoneration has gone hand in hand with martial law. In these cases, all military actions come within the prerogative of the military, who enjoy ex ante permission to do as they see fit to maintain public order (Hussain 2003; Dyzenhaus 2009; Reynolds 2017). Gradually, legal officials wishing to comply with an evolving law-abiding ethos, especially in the British Empire, abolished this sweeping exoneration and replaced it with a codified set of rules typical of emergency regimes in modern times (Hussain 2003; Neocleous 2006; Reynolds 2017).

In recent years, however, scholars and commentators have reconsidered the possibility of exoneration in cases of torture. According to some, a legal provision that grants a sweeping permission to use violent interrogation methods to save human lives is undesirable but may, in some cases, nevertheless be justified. Applied on a case-bycase basis, and sanctioned by a criminal court, an ex post factum exoneration from criminal liability reflects a greater adherence to the rule of law than a codified emergency regime. Ex post factum exoneration provides a balance between the reluctance to permit abhorred interrogation methods and the perception that they may be justified despite their illegality (Gross 2007; Ramraj 2008; Allhoff 2011). These commentators often quote the $1999 \mathrm{HCJ}$ ruling as a model that reflects such a balance. Others, however, criticize this ex post factum variant of criminal exoneration, arguing that it implies that a rational cost/benefit calculation may justify the use of torture if it yields proportional results (Chesterman 2006; Ginbar 2009).

Be that as it may, in the two decades that have passed since the HCJ ruling, Israel has repeatedly emphasized that the sweeping suspension of the Landau Commission's (1987) report is no longer in force. Both in international and in domestic forums, Israel has argued that the use of violent interrogation methods is not sanctioned by any predetermined set of rules or guidelines, that the existing legal regime allows for a casespecific examination of the costs and benefits of using "extraordinary" interrogation methods, ${ }^{9}$ and that interrogators should be able to benefit from the same criminal defense as everyone else. The HCJ ruling has attracted international attention, with scholars praising its progressive, restrained approach to security-related state violence (Parry and White 2001; Goldstone 2006).

\section{Second Fracture: Time}

Had it stood on its own, the exemption from criminal liability might have led to a situation in which a criminal court would assess whether an interrogator used violence in order to save lives and, if so, should be exempt from criminal liability. That would

9. See, for example, Israel's periodic report to the UN Committee for the Prevention of Torture from 2001, explaining the significance of the HCJ 1999 ruling (United Nations Office of the High Commissioner on Human Rights 2001). See also the state's response to the petition in Tbeish v. Attorney General (2018) at http://stoptorture.org.il/\%D7\%91\%D7\%92\%D7\%A5-901817-\%D7\%A4\%D7\%90\%D7\%A8\%D7\%A1\%D7\%98\%D7\%91\%D7\%99\%D7\%A9-\%D7\%95\%D7\%90\%D7\%97-\%D7\%A0-\%D7\%94\%D7\%99\%D7\% 95\%D7\%A2\%D7\%9E\%D7\%A9-\%D7\%95\%D7\%90\%D7\%97/ (in Hebrew). 
have been substantially different from the sweeping emergency regime created by the Landau Commission's (1987) report. However, one can only guess what the considerations of such a court might have been, as no such case has ever been tried in any criminal court in Israel. ${ }^{10}$ Instead, the prosecution authorities created another legal construct: the legal category of "ticking bomb interrogations," which regulates the exclusion of certain periods of time from the prohibition on the use of violent methods in ISA interrogations. ${ }^{11}$

In its 1999 ruling, the HCJ instructed the Attorney General to publish and distribute guidelines specifying when the defense of necessity would be applicable to ISA interrogations (Public Committee against Torture in Israel 1999, 38), and, shortly after the ruling, the Attorney General did just that. ${ }^{12}$ Based on these guidelines, the ISA developed a procedure by which ISA interrogators can consult their superiors concerning the periods of the interrogation that can be suspended from the prohibition on the use of violent methods of interrogation. This procedure of consultation has recently been approved in a HCJ ruling (Tbeish v. Attorney General 2018).

Suspensions of ordinary law are commonly based on temporal justifications (Gross 2000; Loevy 2016). The underlying logic of legal constructs such as emergencies, temporary orders, and martial law is that times of war or violent political strife are exceptional times, in which the temporary suspension of ordinary law is justified to avoid great harm (Rejali 2007; Reynolds 2017; Loevy 2016). The rationale for this justification is, inter alia, that it is a temporary measure that does not reflect the credo of the society. By using temporariness as their prime justification, regimes can allocate rights in a differential way while, at the same time, maintaining their law-abiding image (Viterbo 2014; Reynolds 2017; Dudai 2018).

The legal, as well as the popular, discourse on torture points to a slightly different aspect of temporality: urgency. Harsher interrogation methods are justified because they will accelerate the gathering of information, thereby preventing an imminent danger, such as a bomb that is about to explode, and thus save human lives (Scheppele 2005a; Gross 2007; Luban 2014; Loevy 2016). ${ }^{13}$ Obviously, these two aspects of

10. As of January 2020, no complaint of torture or ill-treatment has led to the pressing of charges. See Public Committee against Torture in Israel 2009. In January 2018, the state reportedly launched a criminal investigation against two ISA interrogators (see Berger 2018). This, however, did not yield charges.

11. The state usually refers to this category as "necessity interrogations." For example, see the state's response to the petition in Tbeish v. Attorney General (2018). Only rarely has the state used the term "ticking bomb." See, for example, the state's response in the case of As'ad Abu Ghosh et al. v. Attorney General et al (2012, art. 14): "For this reason, the interrogators thought the interrogee to be a 'ticking bomb' ... and that this is a situation of 'necessity' according to Art. 34 of the Criminal Code." However, these terms all refer to the same regime of temporality in which certain periods of time may be excluded from the prohibition on torture. Additional corroborating material attesting to this use was collected in a request for contempt by the Public Committee against Torture v. State of Israel (1999).

12. The Attorney General's guidelines can be found in the annex of the report by Public Committee against Torture in Israel (2009).

13. Loevy (2016) provides an in-depth analysis of the different temporalities in Public Committee against Torture v. State of Israel (1999) as well as of the role of temporal justifications in the global discourse on torture. I borrow her distinction between temporality and urgency, but, unlike her, I show how they operate as separate justifications for the use of torture. 
temporality - temporariness and urgency - are related. Because the danger is imminent, the window of opportunity is small. However, these two temporal reasonings differ in the way that they are used to justify exceptional measures. Temporariness relates to the mere existence of danger. Urgency relates to the results that may accrue from the use of violence-in this case, the neutralization of the bomb before it explodes. Therefore, urgency requires a legal mechanism for evaluating its effectiveness (Arrigo 2004).

As is typical of emergency legislation, the Landau Commission's (1987) report suspended ordinary law for as long as the special danger persisted. The guidelines drafted by the Attorney General, on the other hand, show a shift from temporariness to urgency. The difference between the two is clarified in the explanatory remarks attached to the Attorney General's guidelines, which were made by Nava Ben-Or, deputy state attorney: "There is a principal difference, in my understanding, between the general threat stemming from activity in a terror organization and the threat stemming from information which relates to a specific activity ... which involves immediate harm to human lives. ... The factor of time, which usually allows the use of other courses of actions, is not helpful in a case of necessity" (Public Committee against Torture in Israel 1999).

In cases of urgency, the guidelines exclude certain periods of time in the interrogation from the prohibition on torture, as exemplified in a case brought before the HCJ in 2012 (As'ad Abu Ghosh et al. v. Attorney General et al. 2017). A petition filed against the Ministry of Justice challenged the ministry's decision not to launch a criminal investigation of interrogators who, the state admitted, had used "special" interrogation methods. In its ruling, the HCJ denied the petition. The state's response brief and the court's ruling included a detailed description of what constitutes a "ticking bomb interrogation," with special emphasis on urgency. In such a situation, ordinary methods of interrogation will not yield the required information, only special methods will do so: "On the very same day on which methods of pressure were used for the first time during the petitioner's interrogation, the petitioner led his interrogators to a laboratory where they found explosives and raw materials for producing them, which could have been used to manufacture additional materials if they had not been seized at that moment" (As'ad Abu Ghosh et al. v. Attorney General et al. 2017, state's response, para. 49).

The apparatus for suspending the law on grounds of urgency rather than temporariness creates a rational as well as a specific justification for suspending the prohibition on the use of violent interrogation methods. It is not a danger that justifies a general suspension of the prohibition; it is the need to quickly obtain information in a specific case that allows for a temporary suspension. Though no exact data exists, ${ }^{14}$ the state has repeatedly claimed that the use of the category of "ticking bomb interrogations" is very rare, a claim that underlines the true singularity, and the necessity, of suspending the prohibition on violent interrogation methods. ${ }^{15}$

14. Non-governmental organization reports do not provide actual numbers for the use of this category. Some reports state that it consists of a small fraction of the files with which they deal. See Public Committee against Torture in Israel 2012.

15. The state has repeatedly claimed that the category is used very rarely. See, for example, Judge Elron's ruling in Tbeish v. Attorney General 2018, art. 28. 
The sweeping suspension created by the Landau Commission's (1987) report was replaced by two designated exceptions to the prohibition on torture, one relating to the perpetrator and the other to periods of time within the interrogation. Together, they have come to govern the use of violent methods in ISA interrogations. As critics have noted, the creation of a mechanism for excluding certain phases of the interrogation from the prohibition on torture has led to a greater use of the narrow exception that the HCJ introduced. This temporal exception has generated rules for the application of the exemption of the interrogator from criminal liability, making it predictable and perhaps more like the sweeping suspension created by the Landau Commission's (1987) report (Mann and Shatz 2010; Luban 2014). I analyze the effect of the aggregation of the different forms of the exception below. For now, it is important to note that the time and the perpetrator are separate components of the interrogation that can be excluded from the scope of ordinary law by means of two distinct legal constructs. In the following part, I examine two additional legal constructs, targeting the interrogee and the location of interrogation.

\section{SUSPENDING SAFEGUARDS}

Procedural and oversight mechanisms are safeguards that watch over the welfare of detainees and limit executive power in criminal procedures (Dripps 1993; De Londras and Davis 2010; Lokaneeta 2011; Carver and Handley 2016). They include the right of a detainee to legal counsel, audio-visual recordings of the interrogations, judicial review of the arrest, and assorted monitoring mechanisms. They reflect the assumption underlying modern liberal legalism that the law must restrict the power of the executive in criminal procedures (Kelly 2009; De Londras and Davis 2010).

While the suspension of safeguards is not tantamount to the direct sanctioning of torture, scholars have noted its role in facilitating the use of violent methods of interrogation (Kelly 2009; Khalili 2012; Carver and Handley 2016). Their role is to detectand perhaps prevent-acts prohibited by the law. When violent interrogation methods are openly sanctioned, safeguards detect excesses. When the sanctioning of such interrogation methods is facilitated by narrow exceptions that are difficult to regulate, they play a crucial role in limiting the use of such exceptions. States use two ways to suspend safeguards and deny potential victims the protection of the law: (1) they may label detainees "special suspects," "security suspects," and the like, and (2) they may label certain spaces "interrogation areas." In the case of ISA interrogees, state authorities do both.

\section{Third Fracture: The Victim}

A typical ISA interrogation begins when the military forces arrest an interrogee and transfer them to a detention facility. The facility's authorities - the army or the Israel Prison Service (IPS) — automatically label such detainees "security suspects" that is, detainees suspected of having committed one or more crimes from a list of 
"security offenses" (Viterbo 2018). ${ }^{16}$ This category exists both in Israeli domestic law and in the legislation of the military regime in force in the OPT, which governs most of the arrests and proceedings of ISA interrogees. ${ }^{17}$

Once labeled "security suspects," interrogees are denied most of the procedural safeguards granted ordinary detainees. For example, under ordinary law, the IPS must bring all detainees before a judge within twenty-four hours of their arrest or within fortyeight hours in special cases. ${ }^{18}$ However, for security suspects, the law extends this period for up to ninety-six hours if the interrogator finds it necessary. The longer the extension, the higher the rank of the officer who must approve it. ${ }^{19}$ The same logic applies to the right to legal counsel. A military decree stipulates that detainees be allowed to see a lawyer immediately. For security suspects, however, the same decree suspends this right, using the same logic: the higher the rank of the officer in charge of the interrogation, the longer he can postpone the meeting with legal counsel. A junior officer can postpone such meetings for up to fifteen days, a more senior officer can do so for longer, and a judge can postpone them for up to sixty days in accumulation. ${ }^{20}$

Since the category of "security suspects" applies to practically all ISA interrogees, the legislature could have formulated the relevant legal provision so that it applies to all ISA interrogations, just as the Landau Commission's (1987) report created a legal construct that applied to all ISA interrogations. It could have stipulated, for instance, that all ISA interrogations are exempt from the requirement to let an interrogee see a judge or a lawyer. Instead, it excluded the interrogee rather than the interrogation. This form of exclusion has two advantages for the executive. First, it makes the suspension of safeguards harder to detect. The category of "security suspects" is located in a very different area of the law-that of criminal procedure rather than in the administrative regulations restraining the executive. This severs the link between the suspension of safeguards and other legal constructs pertaining to the interrogator's conduct since it does not directly and explicitly exempt the executive from any of its obligations under ordinary law (Mann and Shatz 2010).

A second advantage is its flexibility. Since the label "security suspect" indicates that the detainee is suspected of a "security crime," the executive can easily change the list of crimes that fall under this category, as indeed it has done (Shahav 2015; Viterbo 2018). Moreover, it can add additional categories- "serious security crime" and "terror-related crime" — each allowing for a different suspension of the detainee's rights. ${ }^{21}$ A detailed examination of the implications of this fragmentation of the

16. Several laws contain lists of "security crimes," among them the Penal Code (1977); Emergency Regulations (1945); Criminal Procedure (1996).

17. Security Provisions Order (2009). "Security crimes" include a long list of minor infractions, such as youth movement activities or demonstrations.

18. Criminal Procedure (1996), Arts. 29-31.

19. In the Occupied Palestinian Territories, the possibility of postponing judicial review was shortened over the years, until the decree was amended in 2012. It now stipulates that a detainee be brought before a judge as soon as possible and no later than ninety-six hours after arrest (Security Provisions Order 2009, arts. 31a, c. 19). A similar arrangement exists in Israeli domestic security legislation (Counter-Terrorism Law 2016, para. 46a).

20. Decree 1713, 2012, Amendment no. 27. In Israeli domestic security legislation, the Attorney General must provide special authorization to prevent a detainee from meeting with a lawyer for more than thirty days. Counter-Terrorism Law 2016, para. 52.

21. Counter Terrorism Law 2016, Arts. 49-50. 
category of "security suspect," and the subsequent scaled exclusion of the detainees from safeguards, is beyond the scope of this article. For my purposes, it is merely important to note that excluding the interrogee, rather than the interrogation, from the safeguards of procedural rights emphasizes the link between the danger posed by the suspect and the suspension of his rights, making such suspension easier to justify. Labeling detainees "security suspects" has implications beyond the revoking of procedural rights. For example, Israel's National Insurance Law (1995) stipulates that parents of minors who are arrested and labeled "security suspects" will not continue to receive social security payments for them. Clearly, excluding a victim from the boundaries of the community provides a justification for revoking his rights.

\section{Fourth Fracture: Space}

Governments frequently argue that locating a facility outside state borders provides a spatial exception to the prohibition on violent interrogation methods. The bestknown example is the claim that, in facilities outside US territory, authorities can use interrogation methods that are illegal in their own territory (Johns 2005; Scheppele 2005a; Ek 2006; Hajjar 2013; Viterbo 2014). ${ }^{22}$ Israel's fluid territorial borders could provide abundant opportunities for using extraterritoriality as a spatial exception, permitting the use of otherwise forbidden interrogation methods in facilities located outside its territorial borders (Kelly 2006). However, Israeli legal officials have not made such a claim, and, by and large, they do not use the argument of extraterritoriality to sanction violent interrogation methods. Instead, the authorities in charge of detention facilities, mostly the IPS, ${ }^{23}$ have constructed a spatial exception within existing prisons and detention facilities, both within and outside the territorial borders of the state.

Most ISA interrogations take place in special wings of Israeli prisons. Like many other countries, Israel allows certain public representatives to conduct oversight visits at prisons without prior notice, and the Public Defender's Office issues an annual report on such visits (Carver and Handley 2016). However, the ISA has requested that these representatives refrain from entering ISA interrogation zones (Viterbo 2014). ${ }^{24}$ In correspondence on this matter from 2009 onwards, the Ministry of Justice has argued that since attorneys from the Public Defender's Office might represent ISA detainees in the future, such visits might create a potential conflict of interest. Thus, the Ministry of Justice has complied with the ISA's request and created a de facto spatial distinction between the interrogation wing and the rest of the prison or detention facility. ${ }^{25}$

A different justification for excluding an interrogation area from oversight mechanisms is that what happens in them needs to remain secret, lest it harm state security. One example is the obligation to use audio-visual documentation in interrogation rooms. The law only requires the video recording of interrogations of "ordinary"

22. This was reported in the media and generated much debate (see Cole 2009).

23. Facilities that belong to the army are not within the scope of the Public Defender's report.

24. For a detailed description, see https://www.acri.org.il/he/2544.

25. In addition to the areas within prisons, there are probably secret facilities and apartments in which some interrogations take place. The analysis presented here applies to them as well, with the required adaptations (Khalili 2012; Viterbo 2014). 
criminal offenses, exempting many security-related police interrogations as well as all ISA interrogations from the need to document such interrogations (Viterbo 2014). The legislature justified this by accepting the ISA's position that "often interrogees of security crimes undergo preparation organized by the terror organizations ... visual and audio documentation of security interrogations might aid these organizations in learning about what happens during an interrogation" (Adalah et al. v. Minister of Home Front Defense [pending], para. 13). ${ }^{26}$

These two ways of excluding ISA interrogees from the scope of safeguardsexcluding the victim and excluding the space of the interrogation-mirror two concepts in the writings of Giorgio Agamben (1998): "the camp" and "homo sacer." In much of the scholarship following Agamben, "the camp" becomes the spatial illustration of the state of exception, while homo sacer becomes the personal illustration of those subject to it. That is, in the camp, the sovereign power meets the homo sacer when he is stripped bare of his rights (Agamben 1998; Ek 2006; Giaccaria and Minca 2011). The same logic applies to the relations between the spatial and the victim-oriented suspension of safeguards, which are merely two different legal avenues for downgrading the safeguards of ISA interrogees and are not essentially different from each other.

However, the existence of two distinct avenues of designated exceptions does have several implications. To begin with, it allows for the suspension of different safeguards. Safeguards associated with the rights of the detainee, such as the right to legal counsel and the judicial review of arrest, are suspended by denying access to them. Those associated with the oversight of a physical facility and are not attached to any particular individual are suspended by means of a spatial exclusion. In addition, excluding people from certain legal protections according to the crimes they are suspected of having committed makes it easier for critics to identify and challenge it. Human rights organizations have openly challenged legal constructs that exclude the victim. ${ }^{27}$ Whereas these organizations have also found ways to challenge the spatial exceptions described above, it has proven far more difficult to point to the ways in which Israel excludes spaces from scrutiny. The exclusion of space-the interrogation room-from the ordinary legal order is far more elusive. Although neither of these exceptions suspends the prohibition on torture directly, they make it nearly impossible to prove torture has taken place (Mann and Shatz 2010). In the next part, I analyze a recent ruling that demonstrates the effect of the aggregation of the four designated exceptions.

\section{THE SUM OF THE PARTS}

So far, I have identified four types of exceptions that came to govern the use of violent interrogation methods in Israel after the HCJ's 1999 ruling: the exemption of perpetrators from criminal liability; the exclusion of certain periods of time from administrative rules of conduct that usually apply to interrogators; the exclusion of victims from procedural safeguards; and the spatial exclusion of facilities from oversight. I have

26. Explanatory comments from the proposed legislation, quoted in the state's response to a petition filed by human rights organizations.

27. See, for example, position papers on the "Anti-Terror Bill," issued by the Association for Civil Rights in Israel (2011). 
shown that each exception created a narrow, easily concealed, and justified suspension of ordinary law and, in effect, facilitated the suspension of the prohibition on torture. The question, however, remains: has this fractured regime encouraged or, rather, reduced the use of violent interrogation methods?

Estimating the incidence of human rights violations, in general, and torture, in particular, is a complicated task (Landman 2004; Carver and Handley 2016). However, data provided by human rights organizations indicates that the ISA stopped using several violent interrogation methods after the HCJ's 1999 ruling and uses others very rarely. Thus, it seems that the rejection of the sweeping exception created by the Landau Commission's (1987) report did succeed in reducing the use of violent interrogation methods (Parry and White 2001). ${ }^{28}$ Yet these welcome developments do not indicate that designated exceptions always reduce state violence. Rather, they are but one possible outcome of a fractured regime. Critics have long expressed concern that the Attorney General's guidelines, together with the possible exemption of interrogators from criminal prosecution established by the HCJ's 1999 ruling, constitute a mechanism that legal authorities may exploit to systematically sanction violent interrogation methods and that the extent of such sanctioning will be difficult to assess due to the lack of oversight mechanisms (Ginbar 2009; Mann and Shatz 2010; Luban 2014; Viterbo 2014). To use the terminology of this article, the aggregation of designated exceptions can produce a codified set of rules enabling the routine use of violence in ISA interrogations.

A recent $\mathrm{HCJ}$ ruling indicates that this possibility is far from theoretical. A ruling from November 2018 concerns Firas Tbeish, a Palestinian resident of the OPT who was interrogated by the ISA in 2012. In 2013, the Public Committee against Torture in Israel filed a petition on behalf of Tbeish, arguing that the ISA had used illegal violent interrogation methods against him and asking the court to overturn the Attorney General's decision not to launch a criminal investigation of Tbeish's interrogators (Tbeish v. Attorney General 2018). ${ }^{29}$ In addition, the petition asked the court to prevent ISA interrogators from consulting their superior officers about applying the necessity defense to a specific interrogation. The court denied the petition (Ben-Natan 2019).

In its ruling, the HCJ concluded that the use of special means came under the necessity defense and was timed in a way that yielded effective results. In addition, the ruling stated that it found no support for the complainant's description of the special means used. ${ }^{30}$ The lack of effective safeguards and the suspension of oversight mechanisms ensured there was no evidence to support the complaint. Thus, the ruling is an example of how the fractures - the criminal defense, the exclusion of periods of time in the interrogation, and the suspension of safeguards that could provide evidencecan, together, prevent the effective scrutiny of violent interrogation methods.

28. See, for example, the section on Israel in Carver and Handley 2016.

29. A motion for an additional hearing of the case was denied in February 2019. See http://stoptorture. org.il/wp-content/uploads/2019/02/\%D7\%94\%D7\%97\%D7\%9C\%D7\%98\%D7\%94-\%D7\%98\%D7\%91\% D7\%99\%D7\%A9-\%D7\%9E\%D7\%AA\%D7\%95\%D7\%A7\%D7\%9F-1.pdf.

30. Evidence presented by the petitioner, such as complaints to a military judge about ill-treatment during his interrogation as well as medical records attesting to the fact that he had fainted during his interrogation were deemed insufficient. Tbeish v. Attorney General 2018, para. 48. 
Not only does the ruling demonstrate how the conjunction of the different exceptions leads to a de facto sweeping state of exception, but it also shows why such a fractured regime is more advantageous to the executive. Since the different exceptions suspend different parts of ordinary law, the HCJ dealt with the suspensions separately and did not take their accumulative effect into account. While the ruling in Tbeish $v$. Attorney General (2018) repeatedly states that the corroborating evidence was insufficient, the court, bound by the technicalities of legal procedure, did not address the difficulty of obtaining such proof when safeguards are suspended since the petition failed to raise this issue (Ben-Natan 2019). As a result, the court did not acknowledge that the suspension of safeguards facilitates the use of mechanisms that exonerate the interrogator of criminal liability (Mann and Shatz 2010).

More importantly, the HCJ treated the different designated exceptions as falling within the prerogative of different authorities, so that their suspension is based on professional discretion in which the court is reluctant to intervene (Mahmud 1993; Hofnung 2001; Sarat and Clarke 2008). For example, when approving the mechanism that allows for temporal suspensions of the prohibition on violent interrogation methods, the court emphasized that it is not concerned with the authorization of physical means in the interrogation but, rather, with the bureaucratic decision-making process (Tbeish v. Attorney General 2018). In this way, it detached the decision-making procedure from the actual suspension of the prohibition on torture and related to it as a technical, professional mechanism for determining the extent and scope of the criminal defense of necessity on a case-to-case basis.

Thus, although the evidence shows that instances of legally sanctioned use of violent interrogation methods decreased after the HCJ's 1999 ruling, Tbeish v. Attorney General (2018) nevertheless demonstrates the relative ease with which a fractured regime can renew the systematic authorization of state violence. Unlike the sweeping state of exception, aggregated designated exceptions are difficult to identify and challenge and more likely to be upheld in court. By leaving the regime of fractured exceptions intact, the court also left intact the possibility of applying various combinations of the different exceptions and enabled a highly flexible—and unpredictable — suspension of the prohibition on violent interrogation methods.

\section{CLASSIFYING EXCEPTIONS}

This article has presented two ways of legally sanctioning state violence. The first is what I have called "a sweeping state of exception." Even if codified, a sweeping state of exception excludes a certain topic from the ordinary legal rule, or exempts a certain authority from adhering to a prohibition imposed by the law. The second is a situation in which multiple, dispersed legal categories allow for the sanctioning of state violence. Each represents a different paradigm for understanding the relation between the law and state violence: the paradigm of the state of exception and that of "hyperlegality" or the proliferation of the law.

However, the shift in the legal sanctioning of violent interrogation methods in Israel described above demonstrates that suspension and proliferation have much in common. When the Landau Commission (1987) introduced its sweeping exception, 
it not only suspended ordinary law but also specified the circumstances under which an alternative, lesser set of rights can be applied, thus creating an additional category of the law. And by introducing this new category, it justified the use of violent interrogation methods as a rational modus operandi-reasonable, proportional, and necessary. This single category was then replaced by multiple categories, each representing a highly specific, seemingly proportional exception to ordinary law. From this perspective, the difference between the sweeping state of exception and the fractured regime of exceptions is quantitative: In both, legal officials add legal categories that dissociate state violence from brutality and make it more palatable to liberal tastes (Esmeir 2012; Mehozay 2016).

This examination not only allows us to see the relation between the two in terms of "more law" and "less law." I argue that the legal categories that came to govern violent interrogation methods in Israel are in fact fractures of the wholesale prohibition on torture, in the sense that they exclude different components of the interrogation from the scope of ordinary law. The differences between them enable the state to reject the suspension of the prohibition on torture and, at the same time, effectively maintain it. Thus, the list of available forms of exception presented above also helps us understand the relation between proliferation and suspension. Using designated exceptions, lawmakers can specify the terms and circumstances of each state of exception, thereby highlighting the rationality of their application (Esmeir 2012; Luban 2014; Reynolds 2017). Moreover, by aggregating different types of suspensions, states can approve an act of violence while creating a context that allows for its concealment (Khalili 2012; Viterbo 2014). Thus, the interplay between rationalizing violence and silencing it is facilitated by selecting from among the different types of exceptions.

Today, various state policies attempt to tackle crises or thwart activities portrayed as posing a special danger by applying these different types of exceptions: camps are erected to stop immigration; temporal decrees suspend civil rights; detainees are labeled and divided into different categories, with each category granting a different measure of procedural rights; and certain authorities are exempt from fulfilling their obligations. These common ways of responding to crises result in the sanctioning of harsher measures toward marginalized groups. A better understanding of the exclusions engendered by the different types of exceptions can help activists in their struggle to eliminate such exclusions by pointing to the various loopholes they create in the granting of rights.

\section{REFERENCES}

Agamben, Giorgio. 1998. Homo Sacer: Sovereign Power and Bare Life. Translated by Daniel Heller Roazen. Stanford, CA: Stanford University Press.

Allhoff, Fritz. 2011. "Torture Warrants, Self-Defense and Necessity." Public Affairs Quarterly 25, no. 3: $217-40$.

American National Lawyers Guild. 1978. Report of the 1977 Middle East Delegation of the National Lawyers Guild, Treatment of Palestinians in the Israeli-Occupied West Bank and Gaza. New York: National Lawyers Guild.

Amnesty International. 1970. Report on the Treatment of Certain Prisoners under Interrogation in Israel. London: Amnesty International.

Arrigo, Jean M. 2004. "A Utilitarian Argument against Torture Interrogation of Terrorists." Science and Engineering Ethics 10, no. 3: 543-72. 
Association for Civil Rights in Israel. 2011. "Position Paper on the Counter-Terror Bill, 2010." https:// law.acri.org.il/en/2013/06/09/terror-bill/.

Bellamy, Alex J. 2006. "No Pain, No Gain? Torture and Ethics in the War on Terror." International Affairs 82, no. 1:121-48.

Ben-Natan, Smadar. 2019. "Revise Your Syllabi: Israeli Supreme Court Upholds Authorization for Torture and Ill-Treatment." Journal of International Humanitarian Legal Studies 10, no. 1: 41-57.

Berda, Yael. 2017. Living emergency: Israel's Permit Regime in The Occupied West Bank. Stanford, CA: Stanford University Press.

Berger, Yotam. 2018. "A Special Team Is Investigating Why the ISA Ordered Searching a Palestinian Woman's Genitalia." Haaretz, November 1.

Braverman, Irus, Nick Blomley, David Delaney, and Alexander Kedar, eds. 2014. The Expanding Spaces of Law: A Timely Legal Geography. Stanford, CA: Stanford University Press.

B’Tselem. 1992. Detained without Trial. https://www.btselem.org/sites/default/files/sites/default/files2/ detained_without_trial.pdf.

—. 1998. Routine Torture. http://www.hamoked.org/Document.aspx?dID=7240.

Carver, Richard, and Lisa Handley, eds. 2016. Does Torture Prevention Work? Liverpool, UK: University of Liverpool Press.

Chesterman, Simon. 2006. "Secrets and Lies: Intelligence Activities and the Rule of Law in Times of Crisis." Michigan Journal of International Law 28: 553-73.

Cole, Matthew. 2009. "Officials: Lithuania Hosted Secret CIA Prison to Get 'Our Ear'." ABC News, August 20.

Cover, Robert M. 1985. "Violence and the Word." Yale Law Journal 95: 1601-29.

De Londras, Fiona, and Fergal F. Davis. 2010. "Controlling the Executive in Times of Terrorism: Competing Perspectives on Effective Oversight Mechanisms." Oxford Journal of Legal Studies 30: 19-47.

Dershowitz, Alan M. 2003. "The Torture Warrant: A Response to Professor Strauss." New York Law School Law Review 48: 275-94.

Dripps, Donald A. 1993. "Criminal Procedure, Footnote Four, and the Theory of Public Choice: Or, Why Don't Legislatures Give a Damn about the Rights of the Accused." Syracuse Law Review 44: 1079-1101.

Dudai, Ron. 2018. "Restraint, Reaction, and Penal Fantasies: Notes on the Death Penalty in Israel, 1967-2016." Law EO Social Inquiry 43, no. 3: 862-88.

Dyzenhaus, David. 2009. "The Puzzle of Martial Law." University of Toronto Law Journal 59, no. 1: 1-64.

Ek, Richard. 2006. "Giorgio Agamben and the Spatialities of the Camp: An Introduction.” Geografiska Annaler: Series B, Human Geography 88: 363-86.

Esmeir, Samera. 2012. Juridical Humanity: A Colonial History. Stanford, CA: Stanford University Press.

Furedi, Frank. 1993. "Creating a Breathing Space: The Political Management of Colonial Emergencies." Journal of Imperial and Commonwealth History 21: 89-106.

Gaeta, Paola. 2004. "May Necessity Be Available as a Defence for Torture in the Interrogation of Suspected Terrorists?" Journal of International Criminal Justice 2: 785-94.

Gathii, James Thuo. 2003. "Torture, Extraterritoriality, Terrorism, and International Law." Albany Law Review 67: 101-38.

Giaccaria, Paolo, and Claudio Minca. 2011. "Topographies/Topologies of the Camp: Auschwitz as a Spatial Threshold." Political Geography 30: 3-12.

Ginbar, Yuval. 2009. "Celebrating 'a Decade of Legalised Torture in Israel." Essex Human Rights Review 6, no. 1: 169-87.

Goldstone, Richard. 2006. "Combating Terrorism: Zero Tolerance for Torture." Case West Reserve Journal of International Law 37: 343-48.

Gordon, Neve. 2009. Israel's Occupation. Berkeley: University of California Press.

Greenberg, Karen J., ed. 2005. The Torture Debate in America. New York: Cambridge University Press.

Gross, Oren. 2000. "The Normless and Exceptionless Exception: Carl Schmitt's Theory of Emergency Powers and the 'Norm-Exception' Dichotomy." Cardozo Law Review 21: 1825-68. 
- 2007. "Torture and an Ethics of Responsibility." Law, Culture and the Humanities 3: 35-54.

Gutman, Yehiel. 1995. Taltala Bashabak. Tel Aviv: Yedioth Ahronoth (in Hebrew).

Hajjar, Lisa. 2005. Courting Conflict: The Israeli Military Court System in the West Bank and Gaza. Berkeley: University of California Press.

- 2013. Torture: A Sociology of Violence and Human Rights. New York: Routledge.

Hofnung, Menahem. 2001. Israel: Security Needs vs. the Rule of Law. Jerusalem: Nevo Publishing (in Hebrew).

Hofnung, M., and K. W. Margel. 2010. "Judicial Setbacks, Material Gains: Terror Litigation at the Israeli High Court of Justice. Journal of Empirical Legal Studies 7, no. 4: 664-92.

Hussain, Nasser. 2003. The Jurisprudence of Emergency: Colonialism and the Rule of Law. Ann Arbor, MI: University of Michigan Press.

2007. "Beyond Norm and Exception: Guantánamo." Critical Inquiry 33: 734-53.

Imseis, Ardi. 2001. "'Moderate' Torture on Trial: Critical Reflections on the Israeli Supreme Court Judgment Concerning the Legality of General Security Service Interrogation Methods." Berkeley Journal of International Law 19: 328-49.

International Commission of Jurists. 1984. Law in the Service of Man, Torture and Intimidation in the West Bank: The Case of Al-Fara'a Prison. Ramallah, West Bank: Law in the Service of Man, an affiliate of the International Commission of Jurists.

International Committee of the Red Cross. 1968. Report on Nablus Prison. Geneva: International Committee of the Red Cross.

Israeli League for Human and Civil Rights. 1971. The Horrors of Gaza. Tel Aviv: Israeli League for Human and Civil Rights.

Johns, Fleur. 2005. "Guantanamo Bay and the Annihilation of the Exception." European Journal of International Law 16, no. 4: 613-35.

Kahn, Paul W. 2008. Sacred Violence: Torture, Terror, and Sovereignty. Ann Arbor, MI: University of Michigan Press.

Kelly, Tobias. 2006. "Jurisdictional Politics' in the Occupied West Bank: Territory, Community, and Economic Dependency in the Formation of Legal Subjects." Law $\mathcal{E}$ Social Inquiry 31, no. 1: 39-74.

—. 2009. "The UN Committee against Torture: Human Rights Monitoring and the Legal Recognition of Cruelty." Human Rights Quarterly 31: 777-800.

Khalili, Laleh. 2012. Time in the Shadows: Confinement in Counterinsurgencies. Stanford, CA: Stanford University Press.

Landau Commission. 1987. Commission of Inquiry into the Methods of Investigation of the General Security Service Regarding Hostile Terrorist Activity. Jerusalem: Government Press Office.

Landman, Todd. 2004. "Measuring Human Rights: Principle, Practice, and Policy." Human Rights Quarterly 26: 906-31.

Lloyd, David. 2012. "Settler Colonialism and the State of Exception: The Example of Palestine/ Israel." Settler Colonial Studies 2, no. 1: 59-80.

Loevy, Karin. 2016. Emergencies in Public Law: The Legal Politics of Containment. Cambridge, UK: Cambridge University Press.

Lokaneeta, Jinee. 2011. Transnational Torture: Law, Violence, and State Power in the United States and India. New York: New York University Press.

Luban, David. 2014. Torture, Power and the Law. Cambridge, UK: Cambridge University Press.

Mahmud, Tayyab. 1993. "Praetorianism and Common Law in Post-Colonial Settings: Judicial Responses to Constitutional Breakdowns in Pakistan." Utah Law Review 4: 1225-1305.

Mann, Itamar, and Omer Shatz. 2010. "The Necessity Procedure: Laws of Torture in Israel and Beyond, 1987-2009." Unbound: Harvard Journal of the Legal Left 6: 59-110.

Mehozay, Y. 2016. Between the Rule of Law and States of Emergency: The Fluid Jurisprudence of the Israeli Regime. New York: State University of New York Press.

Morgan, Rod. 2000. "The Utilitarian Justification of Torture: Denial, Desert and Disinformation." Punishment \& Society 2: 181-96. 
Neal, Andrew W. 2012. "Normalization and Legislative Exceptionalism: Counterterrorist Lawmaking and the Changing Times of Security Emergencies." International Political Sociology 6: 260-76.

Neocleous, Mark. 2006. "The Problem with Normality: Taking Exception to 'Permanent Emergency." Alternatives 31, no. 2: 191-213.

Nieminen, Kati. 2019. "The Detainee, the Prisoner, and the Refugee: The Dynamics of Violent Subject Production." Law, Culture and the Humanities 15, no. 2: 516-39.

Nowak, Manfred. 2006. "What Practices Constitute Torture? US and UN Standards." Human Rights Quarterly 28: 809-41.

Parry, John T., and Welsh S. White. 2001. "Interrogating Suspected Terrorists: Should Torture Be an Option." University of Pittsburgh Law Review 63: 743-66.

Pascovich, Eyal. 2015. "Not Above the Law: Shin Bet's (Israel Security Agency) Democratization and Legalization Process." Journal of Intelligence History 14, no. 1: 54-69.

Public Committee against Torture in Israel. 2009. "Accountability Denied: The Absence of Investigation and Punishment of Torture in Israel." Stop Torture. December. http://stoptorture.org.il/ accountability-denied-the-absence-of-investigation-and-punishment-of-torture-in-israel-december2009/?lang=en.

— . 2012. "Accountability Still Denied." Stop Torture. http://stoptorture.org.il/wp-content/uploads/ 2015/10/accountability-still-denied-2012.pdf.

Rahman, As'ad Abdul. 1969. Memories of a Prisoner. Beirut: Palestine Research Center.

Ramraj, Victor V., ed. 2008. Emergencies and the Limits of Legality. Cambridge, UK: Cambridge University Press.

Reichman, Amnon. 2001. "When We Sit to Judge We Are Being Judged: The Israeli GSS Case, Ex Parte Pinochet and Domestic/Global Deliberation." Cardozo Journal of International and Comparative Law 9: 41-103.

Rejali, Darius. 2007. Torture and Democracy. Princeton, NJ: Princeton University Press.

Reynolds, John. 2017. Empire, Emergency and International Law. Cambridge, UK: Cambridge University Press.

Robinson, Shira N. 2013. Citizen Strangers: Palestinians and the Birth of Israel's Liberal Settler State. Stanford, CA: Stanford University Press.

Sa'di, Ahmad H. 2016. Thorough Surveillance: The Genesis of Israeli Policies of Population Management, Surveillance and Political Control towards the Palestinian Minority. Manchester: Manchester University Press.

Sarat, Austin, and Conor Clarke. 2008. "Beyond Discretion: Prosecution, the Logic of Sovereignty, and the Limits of Law." Law $\mathcal{E}$ Social Inquiry 33, no. 2: 387-416.

Scheppele, Kim Lane. 2005a. "Hypothetical Torture in the 'War on Terrorism'." Journal of National Security Law and Policy 1: 285-340.

—. 2005b. "Small Emergencies." Georgia Law Review 40: 835-1245.

Shahav, Sigal. 2015. "Legal and Social Aspects of the Prosecution of Security Suspects: Security Criminal Law vs. Ordinary Criminal Law." PhD diss., Faculty of Law, Tel Aviv University (in Hebrew).

Shenhav, Yehouda. 2012. "Imperialism, Exceptionalism and the Contemporary World." In Agamben and Colonialism, ed. Marcelo Svirsky and Simone Bignall, 17-31. Edinburgh: Edinburgh University Press.

Sunday Times. 1977. "Israel Denies Allegations of Torturing Arabs," June 22.

Townshend, Charles. 1982. "Martial Law: Legal and Administrative Problems of Civil Emergency in Britain and the Empire, 1800-1940." Historical Journal 25: 167-95.

United Nations Economic and Social Council. 1970. Report of the Special Committee to Investigate Israeli Practices Affecting the Human Rights of the Population of the Occupied Territories, Doc. A/8089, October 5. https://unispal.un.org/UNISPAL.NSF/0/BC776349EAEE6F28852563E6005EDF08.

United Nations Office of the High Commissioner on Human Rights. 2001. Consideration of Reports Submitted by State Parties under Article 19 of the Convention, Doc. CAT/C/54/Add.1, July 4. https://tbinternet.ohchr.org/_layouts/treatybodyexternal/Download.aspx?symbolno=CAT\%2fC $\% 2 f 54 \% 2 f$ Add. $1 \&$ Lang $=$ en. 


\section{LAW \& SOCIAL INQUIRY}

Viterbo, Hedi. 2014. "Seeing Torture Anew: A Transnational Reconceptualization of State Torture and Visual Evidence." Stanford Journal of International Law 50: 281-317.

2018. "Rights as a Divide-and-Rule Mechanism: Lessons from the Case of Palestinians in Israeli Custody." Law $\mathcal{E}$ Social Inquiry 43, no. 3: 764-95.

\section{CASES CITED}

As'ad Abu Ghosh et al. v. Attorney General et al., HCJ 5722/12 (2017).

Adalah et al. v. Minister of Home Front Defense et al., HCJ 5014/15 (pending).

Izzat Nafsu v. Attorney General, HCJ 88/88 (1988).

Lieutenant Izzat Nafsu v. Chief Military Advocate, CA 124/87 (1987).

Public Committee against Torture v. State of Israel, HCJ 5100/94, IsrSC 53(4), 817 (1999).

Tbeish v. Attorney General, HCJ 9018/17 (2018).

\section{STATUTES CITED}

Criminal Procedure (Enforcement Powers-Detention), 5756-1996, Sefer Hahukim 5756, no. 1592, 338 , as amended.

Counter-Terrorism Law, 5766-2016, Sefer Hahukim 5766, no. 2556, 898.

Defence Emergency Regulations, 1945.

Security Provisions Order (Amendment no. 27) (no. 1713) 5762-2012.

Security Provisions Order (no. 1651), 5769-2009 [Consolidated Version].

Penal Code, 5737-1977, Sefer Hahukim 5737, no. 864, 226, as amended.

National Insurance Law, 5755-1995, Sefer Hahukim 5758, no. 1522, 210, para. 325(b-c), as amended (consolidated version). 